\title{
Aluzje eucharystyczne w Liście do Hebrajczyków
}

\author{
Kamil P. Mańka
}

Kraków

manka.kamil@gmail.com (1) https://orcid.org/0000-0002-9143-1580

Na przestrzeni lat pojawiło się kilka propozycji sugerujących obecność aluzji eucharystycznych w Liście do Hebrajczyków ${ }^{1}$, spotykają się one jednak zazwyczaj z krytyką. Rzecz rodzi tak duży spór ze względu na szczególny charakter Listu. Nie tylko jest on najprawdopodobniej jedynym pismem swojego autora, które się zachowało, ale sam w sobie jest niezrównany pod względem swej wizji i teologicznego podejścia. Prawie nic nie wiadomo o autorze, ani o wspólnocie, do której pismo to zostało skierowane. Ponieważ nawet bardzo podstawowe zrozumienie Listu wymaga od razu znaczącej rekonstrukcji tła jego powstania, staje się on żyzną glebą dla przeróżnych interpretacji. Wzmaga się to tym bardziej, gdy postuluje się w treści Listu obecność jakichkolwiek aluzyjnych odniesień. W tym wypadku bowiem wkraczamy w sferę celowej wieloznaczności słów autora. $Z$ tego powodu zawsze trudno będzie przedstawić mocny argument przemawiający za eucharystycznymi aluzjami w Liście do Hebrajczyków, jak i ich całościowe wyjaśnienie.

W niniejszym artykule chciałbym dodać do trwającej na ten temat dyskusji dwa zastrzeżenia, jak również zaproponować analizę dwóch fragmentów Listu, mając owe zastrzeżenia na uwadze. Pierwsze zagadnienie to idea „strzeżenia świętej formuły” wyrażona przez Joachima Jeremiasa, druga to odczytanie Chrystusowej ofiary w Liście do Hebrajczyków zasadniczo nie w kategoriach śmierci na krzyżu, ale ofiarowania zmartwychwstałego Chrystusa w niebie wedle wyjaśnienia Davida Moffitta. Teksty, które zostaną poddane analizie w artykule, to Hbr 9, 19-22 i 13, 9-13.

1 P. Andriessen, L'Eucharistie dans l'Epître aux Hébreux, „Nouvelle Revue Théologique” 94 (1972) nr 3, s. 269-277; C. Spicq, L'Épître aux Hébreux, Paris 1957; J. Swetnam, Christology and the Eucharist in the Epistle to the Hebrews, „Biblica” 70 (1989) nr 1, s. 74-95. Por. również krytyczne omówienie różnych propozycji w R. Williamson, The Eucharist and the Epistle to the Hebrews, „New Testament Studies” 21 (1975), s. 300-312, https://doi.org/10.1017/S0028688500011048. 


\section{Strzeżenie świętej formuły}

Joachim Jeremias wskazywał na to, jak od bardzo wczesnego etapu rozwoju pojawiły się w pierwotnym chrześcijaństwie sposoby chronienia świętego rytuału Wieczerzy Pańskiej². Wymienia następujące przykłady:

- używanie pseudonimicznych określeń na rzeczony rytuał;

- ograniczenie dostępu do nauczania o nim do wtajemniczonych;

- ukrywanie szczegółów rytuału;

- tylko częściowe przytaczanie formuły eucharystycznej33.

Początkową zachętą do zbadania tego wymiaru przekazu tradycji eucharystycznej było dla niego pozorne milczenie Ewangelii Jana na temat rytuału Wieczerzy Pańskiej. W przypadku Hbr sugeruje on, że nieobecność Eucharystii na liście fundamentalnych nauk dla neofitów w Hbr 6, 1-3 jest świadectwem

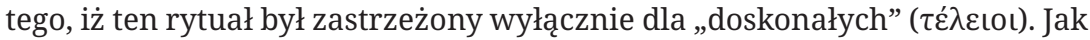
sądzę, ogólne wnioski Jeremiasa ${ }^{4}$ na temat strzeżenia świętej formuły można zastosować również do odczytania innych fragmentów Listu, co też postaram się niżej zaprezentować.

Gdy omawiamy problem „świętej formuły”, w sposób nieuchronny natrafiamy na kwestię recepcji tradycji Wieczerzy Pańskiej (recepcji rytuału) przez autora i odbiorców Hbr. Williamson, komentując Hbr 9, 20, stawia ten problem w następujący sposób: „Czy nie jest możliwe, że [autor Hbr] był świadom tradycji słów Jezusa związanych z Ostatnią Wieczerzą, ale należał do pierwotnej chrześcijańskiej wspólnoty, która, kierowana być może jego własnym wyjaśnieniem natury odkupieńczego dzieła Chrystusa, nie podzielała tego, co zdaje się być powszechną wiarą i praktyką eucharystyczną wczesnego Kościoła?”5. Sytuacja przedstawiona w tym cytacie wydaje się być nieprawdopodobna, gdyż wymagałaby jawnej niekonsekwencji autora Hbr. Pomimo korzystania z przekazu fundamentalnego dla praktyki eucharystycznej ${ }^{6}$ musiałby odrzucić samą praktykę, a zachować tradycję. Sama zaś tradycja

2 J. Jeremias, The Eucharistic Words of Jesus, S. C. M. Press, London 1966, s. 125-137.

3 Tamże, 136.

4 Tamże, 137.

5 „Is it not possible that he was aware of a tradition of Jesus' words connected with the Last Supper but that he belonged to an early Christian community which, prompted perhaps by his own exposition of the nature of the redemptive work of Christ, did not share in what appears to have been the common eucharistic faith and practice in the Early Church?” (R. Williamson, The Eucharist and the Epistle to the Hebrews, dz. cyt., s. 306).

6 Tj. opowieści o ustanowieniu Wieczerzy Pańskiej (por. 1 Kor 11, 23-25). 
nie wydaje się być centralna dla jego rozumienia ofiary Chrystusa $^{7}$, a przez to jej oddzielenie od praktyki nie zdaje się być warte wysiłku autora. Bardziej zadowalającym wyjaśnieniem może być to, że autor posługuje się tradycją eucharystyczną okazyjnie, by wesprzeć swoją argumentację skoncentrowaną wokół innych kwestii. Jednak, jak będę przekonywał niżej, rola tradycji i praktyki eucharystycznej w Hbr może być również widziana w świetle świętej formuły, która może wyjaśnić, dlaczego praktyka eucharystyczna wydaje się być nieobecna w ramach teologicznych Listu.

Komentatorzy zwracają uwagę na to, że autor Hbr mógłby przy wielu okazjach poczynić jasne odniesienie do Eucharystii, jednak nie wykorzystuje tych możliwości ${ }^{8}$. Intencjonalne pominięcie takich odniesień może być nie tylko znakiem odrzucenia Eucharystii, ale przeciwnie - znakiem czci, która skłania autora do okrycia milczeniem świętego rytuału lub czynienia aluzji czytelnych wyłącznie dla wspólnoty. Dlaczego autor mógłby chronić Eucharystię przed wzmiankowaniem jej w sposób otwarty? Jeśli Hbr jest homilią dostarczoną w formie listu, tzn. niewygłoszoną przez samego autora, ale zabraną przez kogoś do wspólnoty, by ją tam odczytać, istniało ryzyko przechwycenia dokumentu przez osoby trzecie. $\mathrm{W}$ takim wypadku praktyka eucharystyczna wspólnoty pozostałaby zakryta dla niewtajemniczonych za sprawą aluzji i niedopowiedzeń. Poniżej omówię dwa konkretne przypadki możliwych aluzji eucharystycznych i postaram się ocenić je w świetle tezy o świętej formule.

\section{Krew przymierza}

Pierwszym tekstem, który chciałbym poddać analizie, jest opis inauguracji przymierza synajskiego, jaki znajdujemy w Hbr 9, 19-22:

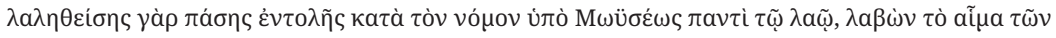

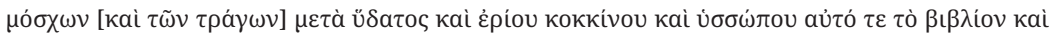

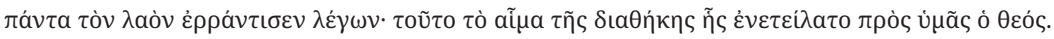

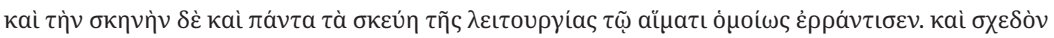

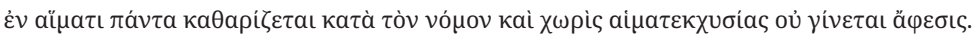

7 Por. D. M. Moffitt, Atonement and the Logic of Resurrection in the Epistle to the Hebrews, Brill, Leiden 2011, https://doi.org/10.1163/ej.9789004206519.i-338.

8 Na przykład 6, 4-5; 7, 1-8; 9, 19-22; 10, 19-20; 13, 9-11. 
Bowiem gdy wszelkie przykazanie Prawa zostało ogłoszone przez Mojżesza całemu ludowi, wziąwszy krew wołów [i kozłów] wraz z wodą i szkarłatną wełną oraz hizopem, samą księgę i cały lud pokropił, mówiąc: «To [jest] krew przymierza, które nakazał dla was Bóg». A i namiot, i wszystkie naczynia służby liturgicznej podobnie krwią pokropił. I rzeczywiście za pomocą krwi wszystko oczyszcza się według Prawa i bez wylania krwi nie dokonuje się odpuszczenie ${ }^{9}$.

Historia jest opowiedziana przez autora w kilku krokach, których sekwencja jest następująca:

1. Mojżesz uczy lud wszystkich przykazań;

2. bierze krew i wodę i skrapia nimi księgę Prawa oraz lud;

3. następnie ogłasza: „To jest krew przymierza, które Bóg ustanowił dla was”;

4. wreszcie przybytek i jego naczynia dostępują również pokropienia.

Wszystko to kończy się dwoma uwagami autora: według Prawa wszystko jest oczyszczane krwią, a odpuszczenie ma miejsce tylko przez przelanie krwi. Kolejne wersety opisują, jak Chrystus przez swoją krew oczyścił niebiański przybytek i dokonał ofiary za grzechy (Hbr 9, 23-26). To odpowiada punktowi 4 w sekwencji opisanej powyżej - oczyszczenie niebiańskiego przybytku jest paralelne do pokropienia przybytku ziemskiego. Co można powiedzieć o pozostałych trzech punktach? Jak często wskazywano, ogłoszenie przymierza w punkcie 3 można rozpatrywać jako aluzję do formuły z Ostatniej Wieczerzy:

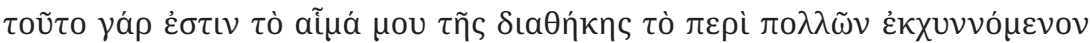

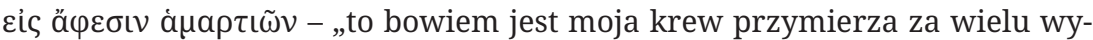
lewana na odpuszczenie grzechów” (Mt 26, 28) ${ }^{10}$. Jeśli jest to do przyjęcia, można zastanowić się, czy istnieją dalsze odpowiedniki w takiej sekwencji. I w istocie ogłoszenie krwi przymierza w Ostatniej Wieczerzy jest poprzedzo-

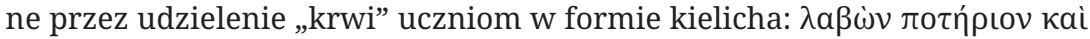

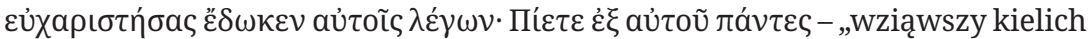
i złożywszy dziękczynienie, dał im mówiąc: Pijcie z tego wszyscy” (Mt 26, 27). Dopiero po tym Jezus wyjaśnia sens kielicha, tak jak Mojżesz uczynił z pokropieniem ludu w punkcie 2. To powiązanie jest wzmocnione przez kolejne podobieństwo leksykalne (zdradzające jego skostniały, cechujący rytualne for-

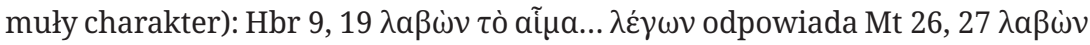

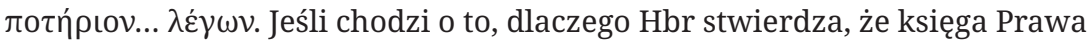

9 Jeśli nie zaznaczono inaczej, wszystkie przekłady biblijne są dziełem autora.

10 P. Andriessen, L'Eucharistie dans l'Epître aux Hébreux, dz. cyt., s. 274. 
została pokropiona razem z ludem, zostanie to omówione wkrótce poniżej. Wreszcie, wydaje się słusznym stwierdzić, że jak Mojżesz zainaugurował przymierze po ogłoszeniu wszystkich przykazań Prawa w punkcie 1, tak Jezus ogłosił nowe przymierze po zakończeniu swej służby nauczania. Jeden ostatni szczegół wypada zauważyć: poza paralelizmami w tym schemacie „proceduralnym” dostrzec można również podobieństwo frazeologiczne po-

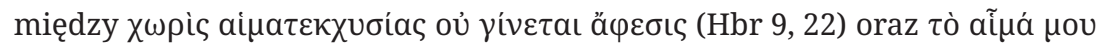

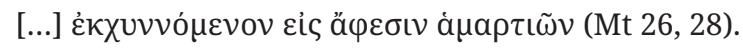

Chociaż można by argumentować, że owe paralelizmy są przypadkowe, a wynikają z opierania się na tych samych źródłach (np. Wj 24), trzeba zauważyć, że Hbr nie odzwierciedla wiernie historii z Księgi Wyjścia 24, w której Mojżesz odczytuje Prawo ludowi, ten zgadza się go przestrzegać, a następnie kropi go krwią, ogłaszając ustanowienie przymierza (nie ma wzmianki o pokropieniu księgi Prawa). Inną modyfikacją jest dodanie wody do obrazu pokropienia w Hbr, która jest nieobecna w Wj. Przywodzi to na myśl J 19, 34, gdzie krew i woda wypływają z przebitego boku Jezusa, jak również wczesnochrześcijańską praktykę mieszania wina i wody w rytuale eucharystycznym ${ }^{\mathbf{1 1}}$. Po rytuale krwi przymierza Mojżesz wraz ze starszymi Izraela natychmiast wstępuje na górę, by ujrzeć Boga. Poświęcenie przybytku ma miejsce wiele rozdziałów później (w Wj 40) i nie zawiera żadnego pokropienia krwią. Hbr z drugiej strony sugeruje, że przybytek został pokropiony tą samą krwią, której użyto do pokropienia księgi i ludu. W ten sposób autor listu stara się zachować ciągłość pomiędzy obiektami skropionymi tą samą krwią. Ponieważ celem całego tego tekstu jest biblijny komentarz do ofiary Chrystusa i jego krwi w szczególności, powinno się prawdopodobnie rozumieć, iż autor konstruuje w ten sposób analogię, którą należy odczytywać w świetle Chrystusa. Odniesienie do tradycji Ostatniej Wieczerzy lub nawet do tej tradycji w takiej formie, jak została uwieczniona w szerszej narracji Ewangelii, ${ }^{12}$ znacząco pomaga wyjaśnić szczegóły zmodyfikowanego obrazu inauguracji przymierza na Synaju, który przedstawia Hbr.

11 Por. Justyn Męczennik, Apologia pierwsza, 1.65.

12 Istnieje możliwość, że autor Hbr zna jakąś formę narracji o męce podobną do tych zachowanych w kanonicznych Ewangeliach. Wskazywać na to mogą: (1) Hbr 5, 7-8 jako odwołanie do modlitwy w Getsemani (Mt 26, 36-46, Mk 14, 32-42; Łk 22, 39-46), (2) Hbr 13, 12-14 jako odwołanie do cierpienia Jezusa poza miastem (Mt 27, 32-37, Mk 15, 21-26, Łk 23, 26-34, J 19, 17-27). Zasadnym jest pytanie, czy autor był zaznajomiony również z taką formą narracji o męce, która zaczyna się od ustanowienia Wieczerzy Pańskiej. 
Aby jednak wyjaśnić kwestię wzmianki o pokropieniu księgi Prawa w Hbr 9, 19, trzeba wrócić do cytatu z proroctwa Jeremiasza na temat nowego przymierza w rozdziale poprzednim. Tam w Hbr 8, 10 nowe przymierze charakteryzuje się złożeniem praw Pana we wnętrzu ludu:

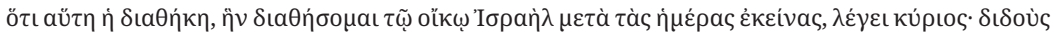

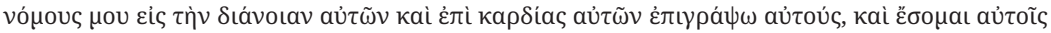

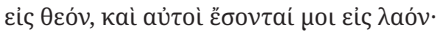

Takie bowiem będzie przymierze, które ustanowię dla domu Izraela po owych dniach, mówi Pan. Złożę prawa moje w ich umyśle i na ich sercach je wypiszę, i będę im Bogiem, a oni będą mi ludem.

Jeśli boskie prawa są teraz wypisane w sercach ludzi, a autor Hbr przywołuje inaugurację przymierza Mojżeszowego jako analogię dla nowego przymierza, to połączenie Prawa i ludu w jednym akcie pokropienia staje się zrozumiałe - w nowym przymierzu Boże prawa złożone są w sercach ludzi. Z drugiej strony, jeśli odwrócić to rozumowanie, można spytać: jeśli Prawo teraz znajduje się w sercach ludu, w jaki sposób te nowe „księgi” Prawa mogą zostać pokropione krwią nowego przymierza? W istocie Hbr 10, 21 mówi o sercach chrześcijan jako pokropionych, ale nie dostarcza nam informacji o tym, że są pokropione krwią. To może być wniesione z innych tekstów, które mówią o pokropieniu i zawsze łączą je z użyciem krwi (9, 13. 19. 21; 12, 24). Serca wiernych byłyby wtedy pokropione krwią Chrystusa poprzez udział w rytuale Eucharystii. Wszystkie powyższe obserwacje wskazują na eucharystyczne rozumienie omawianego tekstu, jednak pomocnym będzie ocenić tę propozycję również w świetle praktyki „ochrony świętej formuły”.

Jeśli u podstaw tego tekstu znajduje się rytuał eucharystyczny, można lepiej zrozumieć, dlaczego autor przywołuje inaugurację przymierza Mojżeszowego bez podania kompletnej paraleli w odniesieniu do Chrystusa, w świetle której można by ją jasno odczytać. Zamiast tego zmienia opowieść z Księgi Wyjścia tak, aby paralela ta mogła zostać rozpoznana dzięki ujęciu tej opowieści w ramy znajomej odbiorcom sekwencji elementów rytuału Eucharystii, jak również poprzez częściowe echa tradycyjnej formuły. Dla kogoś niezaznajomionego z rytuałem i jego źródłową opowieścią ta przetworzona historia może brzmieć nieco dziwnie, ale dla tych, którzy przyzwyczajeni są do brania udziału w Wieczerzy Pańskiej, aluzje będą jasne. Wniosek, jaki stąd wypływa, 
jest taki, że picie z eucharystycznego kielicha odpowiada w myśli autora Listu do Hebrajczyków pokropieniu krwią przez Mojżesza.

\section{Ofiarowanie wcielonego Chrystusa}

Zanim przejdziemy do następnego fragmentu, warto podkreślić niektóre z konsekwencji tezy Davida Moffitta, o której była już mowa, tzn. że ofiara Chrystusa w Hbr to nie śmierć na krzyżu, ale przedstawienie zmartwychwstałego Chrystusa Bogu w niebie. Jeden z zarzutów skierowanych przeciwko eucharystycznemu odczytaniu Hbr wyrasta stąd, że mowę Hbr o krwi Jezusa rozumie się jako metonimię jego śmierci na krzyżu. Łączy się to z szerszym założeniem, iż ogólnie rzecz biorąc, Chrystusowa ofiara miałaby się sprowadzać w ujęciu Hbr do śmierci Jezusa. Ta teza została sfalsyfikowana przez studium Davida Moffitta ${ }^{13}$, który w sposób przekonujący dowodzi, że istotą Chrystusowej ofiary w rozumieniu Listu do Hebrajczyków jest ofiarowanie zmartwychwstałego Jezusa Bogu w niebiańskim przybytku. Częściowo podstawą dla tego wniosku jest fakt, że w żydowskim kontekście kultycznym krew nie jest bynajmniej innym sposobem mówienia o śmierci, a przeciwnie -jest obiektem symbolizującym właśnie życie.

Praca Moffitta dostarcza wielu cennych uwag wobec pytań postawionych w niniejszym artykule. Po pierwsze, pokazuje, jak określona koncepcja (w przypadku Moffitta - cielesne zmartwychwstanie) może funkcjonować jako fundamentalny składnik w teologicznym planie omawianego pisma (Hbr), a jednocześnie może być nierozpoznana przez badaczy z powodu ich teologicznych założeń (o naturze ofiary) lub ze względu na nietypowy sposób mówienia o niej przez autora (Hbr zamiast mówić o zmartwychwstaniu, woli mówić o życiu i wejściu Jezusa do nieba). Po drugie, tak jak z dychotomią wiary i uczynków w korpusie Pawłowym, tak w Hbr istnieją określone założenia dotyczące takich dychotomii, które znajdujemy w liście jak ziemskie-niebieskie, stare-nowe, tego stworzenia-nie tego stworzenia, typ-archetyp itd. Owe dychotomie tradycyjnie wiodły badaczy do interpretowania światopoglądu Hbr w mniej lub bardziej platońskich kategoriach. Jednym z elementów tego założenia było rzekome negatywne podejście autora do materii - to materialność była rozumiana jako jeden z defektów starego kultu, który krytykował

13 D. M. Moffitt, Atonement and the Logic of Resurrection in the Epistle to the Hebrews, dz. cyt. 
Hbr. A jednak w myśl egzegezy Moffitta ${ }^{14}$ ofiarowanie ciała i krwi Chrystusa, jego cielesności, stanowi właśnie treść jego ofiary i to nie za sprawą śmierci, która mogłaby być rozumiana jako zniszczenie ciała Jezusa, ale poprzez cielesne zmartwychwstanie i wywyższenie. Stąd fizyczna natura Chrystusa zyskuje wieczne znaczenie, zaś niebo, gdzie Jezus służy jako kapłan i składa swą ofiarę, nie jest wyłącznie dziedziną odcieleśnionych duchów, ale miejscem zmartwychwstałego, wcielonego Arcykapłana. Taka interpretacja postępuje wbrew odczytaniu Listu z założeniem dualizmu materialność-niematerialność i zmienia uprzedzenia, z jakimi podchodzi się do tekstu.

\section{Spożywanie ciała ofiary pojednania}

Wraz z wnioskami ze studium Moffitta ${ }^{15}$ niektóre sporne fragmenty Hbr mogą zostać odczytane w innym świetle. W szczególności Hbr 13, 9-13 pośród wielu innych interpretacji było widziane jako wyrażające antymaterialistyczny sentyment, być może nawet skierowany przeciwko samej praktyce eucharystycznej ${ }^{16}$.

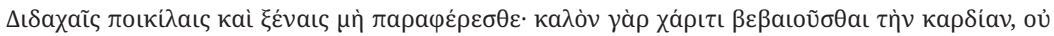

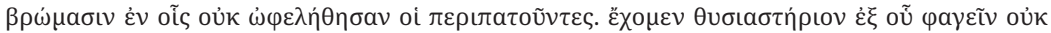

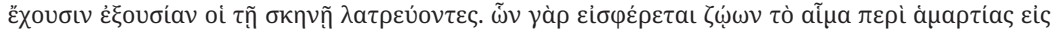

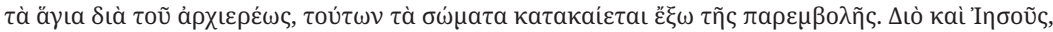

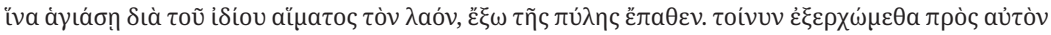

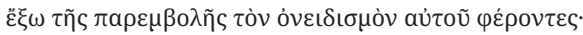

„Nie dajcie się zwieść różnym i obcym naukom. Dobrze bowiem jest łaską umacniać serce, nie pokarmami, które nie przyniosły pożytku przestrzegającym ich. Mamy ołtarz, z którego nie mają prawa spożywać ci, którzy przybytkowi służą. Albowiem zwierzęta, których krew jest wnoszona za grzech do sanktuarium przez kapłana - ich ciała spala się poza obozem. Dlatego też Jezus, aby uświęcić lud swą krwią, poza miastem cierpiał. Zatem wyjdźmy do niego poza obóz, niosąc jego pogardę.”

14 Tamże, s. 229-285.

15 W szczególności jedna z ostatecznych konkluzji jest donośna dla ogólnej interpretacji Listu: „the dualism of Hebrews is not a dualism of flesh-and-blood body vs. spirit” (tamże, 301).

16 J. Moffatt, A Critical and Exegetical Commentary on the Epistle to the Hebrews, T. \& T. Clark, Edinburgh 1924. 
Attridge komentuje ten fragment w sposób następujący: „Możliwe, że znajduje się tutaj jakaś wskazówka, iż ciało Chrystusa podobnie ulega zniszczeniu w jego ofierze i dlatego jest niedostępne do spożycia" ${ }^{17}$. Jednak sens tekstu jest prawdopodobnie całkiem odwrotny. Często zakłada się, że istnieje tutaj konflikt pomiędzy materialnością „pokarmów” i rzekomą niematerialnością „łaski”. Bardziej poprawnym wydaje się być wzięcie całej frazy „pokarmy, które nie przyniosły pożytku tym, którzy ich przestrzegali” jako charakterystykę krytykowanej praktyki. To nie pokarmy jako takie są odrzucane, ale konkretne pokarmy spożywane przez konkretne osoby dla jakiejś korzyści. Właśnie dlatego autor natychmiast powraca do kontrastowania dwóch systemów kultycznych. „Przestrzegający” pokarmów powinni zostać utożsamieni z „tymi, którzy przybytkowi służą”. Z jednej strony, jest powiedziane, że spożywają pokarmy, które nie przynoszą im żadnej korzyści. Z drugiej, nie mogą, jeśli ciała zwierząt ofiarowanych w corocznym święcie Jom Kippur, ponieważ ( yàp) ich ciała ulegają zniszczeniu i są wyrzucane. Chrześcijanie dla odmiany nie troszczą się o pokarmy, które nie przynoszą pożytku, ale mają dostęp do ołtarza, z którego mogą spożywać ciało ofiary. Jeśli wyciągnie się w pełni wnioski z tego zestawienia, można uznać, że ciało, które zostało ofiarowane raz na zawsze w ostatecznym Jom Kippur, o którym mówi Hbr, może być spożywane przez chrześcijan. Ciało Jezusa nie zostało zniszczone ani spalone; cierpiało poza miastem, jak ciała zwierząt ofiarnych są wynoszone poza obóz, ale w przeciwieństwie do nich, ciało Jezusa zostało wzbudzone z martwych i zaprowadzone przed oblicze Boga.

Autor kontrastuje zatem dwa systemy ofiarnicze i w szczególności dwie ofiary pojednania. W systemie lewickim kapłani nie mogą spożywać z ofiary pojednania, tylko ich krew jest użyta w odniesieniu do przybytku. Za to dla chrześcijan rytuał z użyciem krwi został dokonany nie tylko w prototypicznym przybytku w niebie, ale również oni sami zostali uświęceni krwią i mogą spożywać z ofiary pojednania dokonanej na ołtarzu, który być może należy umiejscowić w niebiosach. Znowu należy zapytać, w jaki sposób praktycznie się to dokonuje. Język użyty w tym miejscu jest bardzo aluzyjny, ale trudno uwierzyć, by autor kontrastował konkretne praktyki ziemskich kapłanów z niejasnymi „duchowymi” doświadczeniami wiernych. Na przestrzeni

17 H. W. Attridge, The Epistle to the Hebrews: A Commentary on the Epistle to the Hebrews, Fortress Press, Philadelphia 1989, s. 397: „There may be some hint that the body of Christ is similarly destroyed in his sacrifice and hence unavailable for consumption”. 
całego Listu z wielkim wysiłkiem stara się podkreślić wagę cielesności Jezusa dla złożenia ostatniej, prawdziwej ofiary pojednania z jego krwi i ciała. Po umieszczeniu Jezusowej cielesnej natury w kontekście logiki kultu przybytku wydawałoby się to bardzo dziwne, gdyby w momencie odnoszenia tej ofiary do wiernych powiedział, że mogą oni spożywać z ołtarza jakieś nieokreślone boskie błogosławieństwo. Sensowniej jest przyjąć, że ta emfaza położona na cielesną właściwość Chrystusa działa w obie strony: w odniesieniu do Boga i w odniesieniu do wiernych. Nie neguje to duchowej właściwości całego procesu $^{18}$ ani faktu, że pozostaje on cokolwiek tajemniczy. ${ }^{19}$

Jeśli ofiara Jezusa nie oznacza jego śmierci, ale przyniesienie jego krwi i ciała Bogu w zmartwychwstaniu, jak przekonuje Moffitt ${ }^{20}$, ma to wpływ na to, czego można się spodziewać po wspólnocie Listu do Hebrajczyków w kwestii wiary eucharystycznej. Przesunięcie dokonywałoby się tutaj od śmierci Chrystusa ku jego cielesnej obecności przed obliczem Boga, a jeśli Eucharystia oznacza ofiarę Jezusa, to powinna być rozumiana odpowiednio jako odnosząca się do jego ciała i krwi w niebie.

W kontekście strzeżenia świętej formuły możemy zauważyć, że niniejszy fragment używa pośrednich sposobów, by mówić o rytuale. Znajdujemy mowę o „spożywaniu z ołtarza” i „ciałach” zwierząt złożonych w ofierze pojednania, ale żaden chrześcijański odpowiednik nie jest wprost wskazany. Chrześcijanie mogą odnieść korzyść ze wzmacniania swego serca łaską, ale nie jest wyjaśnione, do czego się to odnosi. Uwaga ta może być odczytywana

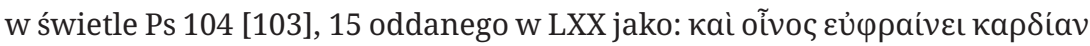

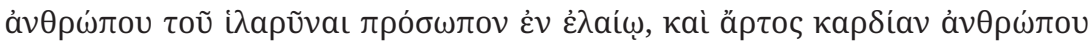

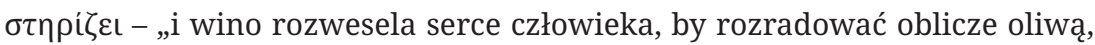
a chleb serce człowieka wzmacnia”, a to z kolei stanowiłoby ponownie zakamuflowane odniesienie do posiłku eucharystycznego. Omawiany fragment cechuje się również napięciem dotyczącym dostępu do obiektów sakralnych: ołtarza, ofiary - kapłani ziemskiej świątyni nie mogą do nich przystąpić, podczas gdy wtajemniczeni chrześcijanie mają przywilej ( $\dot{\xi} \xi o v \sigma i ́ a)$ brać udział w prawdziwym kulcie. Nacisk na dialektykę dostępu i wykluczenia oraz niejasność rzeczywistości, do których autor się odnosi, dobrze odnajdują się wśród praktyk używanych przy ochronie świętych formuł i rytuałów.

18 Chrystusowe samoofiarowanie nadal dokonuje się „przez wiecznego Ducha” (Hbr 9, 14).

19 Ostatecznie można spytać: co to oznacza, że ktoś jest kapłanem i ofiarą jednocześnie?

20 D. M. Moffitt, Atonement and the Logic of Resurrection in the Epistle to the Hebrews, dz. cyt., s. 283-285. 


\section{Podsumowanie}

List do Hebrajczyków na pewno nie został napisany, aby określać lub omawiać w szczegółach praktykę sakramentalną wspólnoty. Nawet jeśli List zakłada tradycję lub praktykę eucharystyczną lub czyni aluzję do nich, nie są one głównym przedmiotem całego jego przesłania. Może nie być jasne, jak dokładnie autor Hbr rozumiał sposób, w jaki Wieczerza Pańska działała w zapośredniczaniu Chrystusowego ciała i krwi, ale jest również możliwe, że sam nie zadawał sobie takiego pytania. Nawet korpus listów Ignacego z Antiochii z jego silnym naciskiem na Eucharystię nie podaje żadnego wyjaśnienia tego, w jaki sposób sakrament ofiarowuje to, co symbolizuje. Takie teologiczne eksploracje pojawią się dopiero później w II wieku, np. w pismach Ireneusza czy Justyna.

Gdyby aluzje do Wieczerzy Pańskiej mogły być odnalezione tylko w Hbr 9, 19 22, gdzie wskazano na silne paralele z historią ustanowienia rytuału, pytanie Williamsona ${ }^{21}$ mogłoby prowadzić do przekonującego poglądu na relację Listu do Hebrajczyków z rytuałem eucharystycznym. Można by wtedy postrzegać Ostatnią Wieczerzę jako niepowtarzalną inaugurację przymierza, taką jak rytuał wykonany przez Mojżesza na Synaju. Jednak liczba możliwych aluzji do rytuału eucharystycznego jest większa i zyskują na znaczeniu, jeśli spojrzy się na nie jako na celowe, zamaskowane odniesienia do tego posiłku. Nie tylko w istocie trudno wyobrazić sobie wczesnochrześcijańską wspólnotę odrzucającą praktykę eucharystyczną, ale przyjmując wnioski Moffitta na temat wagi wcielenia Chrystusa dla Hbr, jest niepojętym, dlaczego wspólnota Listu do Hebrajczyków w szczególności miałaby unikać tego rytuału. Pewien zestaw oczekiwań, z którym podchodzi się do tego listu, musi zostać zrewidowany, szczególnie w odczytaniu dychotomii i przeciwieństw, którymi posługuje się autor.

Wnioski z niniejszego artykułu każą sądzić, że rytuał eucharystyczny jest bliski myśli autora Listu do Hebrajczyków - stanowi jeden z głównych punktów zainteresowania nie tylko w Hbr 9, 19-22, ale powraca również w Hbr 13, 9-13 w zakończeniu dzieła. Zaproponowana tutaj eucharystyczna interpretacja pozwala owe dwa fragmenty nie tylko pełniej zrozumieć, ale również bardziej kompleksowo zintegrować je z przewodnim przesłaniem Listu o ofierze Chrystusa. Wreszcie sam List, przy całej swej wyjątkowości na tle kanonu Nowego Testamentu, okazuje się wyrastać z tradycji i praktyk eucharystycznych znanych z Ewangelii kanonicznych, korpusu Pawłowego

21 Por. R. Williamson, The Eucharist and the Epistle to the Hebrews, dz. cyt., s. 306. 


\section{czy świadectw pierwszych Kościołów, wbrew możliwym platonizującym i antymaterialistycznym interpretacjom.}

\section{Abstrakt}

\section{Aluzje eucharystyczne w Liście do Hebrajczyków}

Artykuł ma na celu dodanie dwóch zastrzeżeń do dyskusji na temat aluzji eucharystycznych w Liście do Hebrajczyków, jak również dostarczyć analizy dwóch fragmentów Listu uwzględniającej owe zastrzeżenia. Pierwsze to propozycja „ochrony świętej formuły” wyrażona przez Joachima Jeremiasa; druga to rozumienie Chrystusowej ofiary w Hbr zasadniczo nie w kategoriach śmierci na krzyżu, ale ofiarowania zmartwychwstałego Chrystusa w niebie wedle wyjaśnienia Davida Moffitta. Omawiane fragmenty Listu to Hbr 9, 19-22 i 13, 9-13.

Słowa kluczowe: List do Hebrajczyków, Eucharystia, ofiara

\section{Abstract}

\section{Eucharistic Allusions in the Epistle to the Hebrews}

The aim of this article is to add two qualifications to the discussion on the topic of Eucharistic allusions in the Epistle to the Hebrews as well as to provide an analysis of two fragments of the epistle that take these qualifications into account. The first is the proposal of the "defense of a holy formula" expressed by Joachim Jeremias; the second is understanding Christ's sacrifice in Hebrews essentially not in categories of death on the Cross but of offering up the resurrected Christ in heaven according to David Moffitt's explanation. The fragments of the epistle under discussion are Hebrews $9: 19-22$ and $13: 9-13$.

Keywords: Epistle to the Hebrews, Eucharist, sacrifice

\section{References}

Andriessen, P. (1972). L'Eucharistie dans l'Epître aux Hébreux. Nouvelle Revue Théologique, 94(3), 269-277.

Attridge, H. W. (1989). The Epistle to the Hebrews. A commentary on the Epistle to the Hebrews (H. Koester, Ed.). Fortress Press.

Jeremias, J. (1966). The Eucharistic words of Jesus (N. Perrin, Trans.). S. C. M. Press.

Moffatt, J. (1924). A critical and exegetical commentary on the Epistle to the Hebrews. T. \& T. Clark. http://archive. org/details/criticalexegetic40moffuoft

Moffitt, D. M. (2011). Atonement and the Logic of Resurrection in the Epistle to the Hebrews. Brill. https://doi. org/10.1163/ej.9789004206519.i-338

Spicq, C. (1957). L'Épître aux Hébreux. Éditions du Cerf.

Swetnam, J. (1989). Christology and the Eucharist in the Epistle to the Hebrews. Biblica, 70(1), 74-95.

Williamson, R. (1975). The Eucharist and the Epistle to the Hebrews. New Testament Studies, 21(2), 300-312. https:// doi.org/10.1017/S0028688500011048 